\title{
ADAPTATION WITH CLIMATE CHANGE AS AN OPPORTUNITY TO RAISE THE QUALITY STANDARDS OF LIFE IN OUR COMMUNITIES
}

\author{
Sherein El-Shahat Akeil ${ }^{1}$
}

\begin{abstract}
:
The risk of climate change is one of the environmental threats on life quality of human and ecosystems. Rising temperatures and humidity are serious impact, which decrease the thermal comfort, raise demand on air conditions, increase droughts, and increase the diseases. Also, sea level rise and extreme events are impacting on coastal areas. In addition to climate change has a range of consequences on health, economic activities and social systems. Responses for climate change are followed mechanisms of mitigation or adaptation, or together. Mitigation has focused on standards, laws, building codes, renewable energy, managing water use, and green areas. There are many adaptation options in urban planning such as urban density adaptation, land use change, institutional adaptation, sustainable development, and landscape of open spaces. Some countries are accelerating the adaptation wheel within their cities. But Egyptian policies should be developed to avoid the future risk on settlements. Hence community's Adaptation is a backbone to improve air quality, decrease demand for energy, and create a space for recreation and ecosystems, and other benefits, which is a huge opportunity to raise quality standards of life in our communities. So, adaptation is adding another value to quality of land use and other socio-economic indicators. [Bul. Soc. Géog. d'Égypte, 2019, 92: 76-89].
\end{abstract}

Key Words: climate change; adaptation; quality of life; urban planning; communities

Abbreviations: Greenhouse Gases (GHGs) - Integrated Coastal Zone Management (ICZM) - Strategic Environmental Assessment (SEA) - Sea Level Rise (SLR) Disaster Risk Reduction (DRR) - Sustainability Assessment (SA).

\section{1- Introduction:}

Quality of life is a wide concept, which has spread since 1940. It refers to status of our whole system, which including the physical (urban, social, and economic) and environmental dimensions in our community. There are many indicators (quantitative and qualitative) to measure the standards of life quality to any community such as resources, education, health, activities, work status, recreation, welfare of well-being, safety, governance, housing, people's rights, natural environment, residential's satisfaction about their life and etc. Others believe that quality of life is only residential's satisfaction about their society. Urban and regional planning are responsible about enhance or raise the quality standards of life. Developers, urban planners and designers should share views and knowledge in this field to improve the settlements. Adaptation with climate change impacts has many positive sides raising the quality standards of life.

${ }^{1}$ Lecturer in environmental and Infra. Planning Dept., Faculty of Regional and Urban Planning.

E-mail: sherein_shahat@nilehi.edu.eg 


\section{2- Research Method:}

The research is mainly depending on the analysis of the climate change impacts and different adaptation responses in light of adaptation barriers. The research also isn't only handling with the mobility from the traditional view (social aspect), but also it is handling with a new concept for the "mobility" term. The research is exposing the different national experts in the field of adaptation with climate change impacts. So, the research is trying to reach to make a synergy to the adaptation process and its reflection on the different aspects.

\section{3- Climate Change Impacts on Settlements:}

The existence of any environmental issue influences negatively on the life quality of human and ecosystems, because it leads to great consequences on life aspects (urban, economic, and social). The risk of climate change is one of these environmental threats. It becomes a dilemma since the last fifty years, with its appeared evidences. It has been resulted by human and natural factors, which caused damage in climate. It is confirmed by certainty of the international community on the issue of global climate change. Due to the increased concentrations of greenhouse gases in the atmosphere, it works on continuation of high temperature, which is a source of drought, extreme events and rising level of seas. These impacts work on losing each of lands, building, infrastructure tourism cultural aspects, natural heritage, agricultural productivity, ecosystems, availability of fresh water, public health, social and economic mobility, changes in the fisheries patterns, coastal recreation areas, and finally coastal navigation. Also, these impacts increase the crowding, poverty, unemployment, negative immigration, energy demand, diseases and etc.

Settlements are facing also rapid growth of population and activities, which will be accelerating the harm by climate change impacts, especially big cities. The circumstances will be worsened in developing counties because of poverty, pollution, arid climate, political changes and climate change impacts. It should be adaptation with climate change impacts, or risk will be doubled.

\section{4- Facing Climate Change in Urban Planning:}

So far, all responses methodologies for global climate change are followed mechanisms of mitigation or adaptation policy with climate change risks, or together, with helping from other programs such as sustainability and disaster programs. Mitigation aims to mitigate greenhouse gases emissions (GHGs) at a huge scale (global or national) through some actions (renewal energy, ICZM, lows), but adaptation (at a regional or local level) aims to reduce the risk of climate change impacts and/or exploit the befits through some practices, policies and strategies adapted from management approaches. Axes to cope with negative impacts are predicting the risk, making restrictions in the areas of risk, and facing the disasters when they occur.

\section{5- Risks and Adaptation Opportunities for Urban Mobility:}

Climate change should be considered in various aspects of urban and environmental planning for the content and the context pattern. Planning includes infrastructure (such as sewer, water, waste, energy, transportation, and telecommunications), open spaces and buildings. Urban designers and architects should create innovative spaces and buildings in light of these impacts. If we do this, it will increase the settlement flexibility to face the climate change impacts, such as the following: 
- Higher temperatures have serious impacts on ecosystem in the summer (thermal comfort).

- With increased temperatures, it increases the demand for artificial cooling (air condition) inside the existing building, especially in high - density areas (such as Cairo City).

- But, if we move towards the natural cooling in urban areas (greenspace, infrastructure, bluespace, open spaces and shading), it will save energy and provide clean environment ${ }^{2}$.

There are many urban designers and architects have developed the planning and design according to local conditions. As for Egypt, local architecture designed by Hassan Fathy is built in spatial buildings suited to desert environment. So, it is an opportunity to adapt with implications to environmental challenges, especially climate change.

While adaptation offers opportunities, there are potential conflicts between different objectives are existing. For example, narrow streets with high buildings can limit risks of high temperatures during the summer, but it may also exacerbate depression during the winter due to over loading in land, energy and resources (overcrowding). Also, it has been designed buildings to reduce energy use for heating in winter that prone to problems in the summer. But at least, if the climate is not considered in the future, we will lose many opportunities.

\section{6- Risks and Adaptation Opportunities of Socio- Economic Mobility:}

Global climate change has serious impacts, which effects on many sensitive areas. Shores, marine life, wetlands, agriculture lands, heritage areas, and other areas are dramatically impacted, which will effect on the social and economic development of settlements. For Egypt, agriculture and fisheries are important sectors for national economies, which face new threats from rising temperatures, soil drought and extreme events. But there are still some opportunities associated with climate change, which can be exploited to raise certain types of agricultural crops, tourism and local industries. Although climate change may destroy some shores, but it has other face. It extends the tourist season in the summer because of increased duration of high temperatures. As temperatures case, it is the same words in changed rainfall.

The availability of financial resources is very important with institutional aspects and possible factors for implementation of adaptation strategies. Also, the existence of social institutions and participation is a vital factor for implementation of adaptation policies. We should upgrade the awareness of the public to use it in good, instead of wasting their efforts.

\section{7- Opportunities for Adaptation Options:}

Adaptation is offered several opportunities to our urban, social, economic mobility of communities. Vegetation is increasing the sand stabilization against shores erosion, visual views to our districts, cleaning the polluted air (air quality), decreasing surface runoff, decreasing heat stress, shading to walkers, representing a collection point for all events and etc. Blue spaces (fountains in squares, ponds, pools) are increasing the evaporation. As we mentioned before, decreased energy from natural cooling is reducing demand for power. Owners of such these buildings are added another value for residents because of improving the life quality standards.

From these examples, we can collect more parities on the table of stakeholder's participation, while we encourage the individual efforts towards the renewable energy, vegetation and other positive actions.

\footnotetext{
${ }^{2}$ WHO, 2008.
} 


\section{8- Adaptation Options:}

\section{7-1-Practices in Planning as a Major Support to Adaptation:}

Planning is very essential for our life to prevent rampant growth in urban and activities. Decision making has a very long effect on the future of area mobility, because its impact can extend to decades or centuries. Decision can accelerate the risk or prevent the harm. Adaptation decisions should be based on precise and specific data and information to conclude correct scenarios (risk prediction), because we deal with an uncertainty level (probabilistic approach). Local and appropriate materials are the best resources for the economic and social side, when we are implementing the adaptation decisions. We should formulate a framework for studying and evaluating every decision before implementation step. Strategic Environmental Assessment (SEA) is used to assess the most investment projects, especially in vulnerable areas. Sustainability, equity, safety, life quality and benefits are the vital corners of socioeconomic circumstances in every community, which should be considered in adaptation plans.

Identification of adaptation options in most cases is through the concerned authorities or/and by discussion of proposed options, costs and barriers in various sectors in urban areas. These adaptation options can be adopted in the ecological and urban areas as following:

- Providing data about climate change and integrated studies for needs of urban planners.

- Cooperation between planners and scientists is to provide guidelines (information from satellite and others). In addition to use different experiences other specifications, such as social and economic knowledge.

- Analyzing the previous experience (local, international), which have similar type of risk. They have been mapped the risk of climate change impacts to conclude the appropriate urban tools to control in heat stress, sea level rise (SLR) or etc.

- Precisely mapping the risk zones (evaluating the weakness).

- Determining the abilities to every zone (services, open spaces, infrastructure, and low lying areas to store flooding water).

- Upgrading some abilities to manage extreme events (such as infrastructure and facilities).

- Avoiding building or planning (land use or infrastructure) in high risked areas to SLR.

- Protecting the existed buildings in the risked areas to SLR by new coastal engineering or upgrading the existed methods.

- Increasing the vegetation (at open spaces, building elevation, or roofs), especially on low lying areas.

- Increasing the water swales on the road side to prevent from flooding.

- Modifying the building codes to reduce energy needs for cooling or to accommodate building upon sea level.

- The caution interference approach with the investments and services in risked areas to SLR at coastal zones.

- The use of permeable surfaces to flooded water whenever possible in urban areas.

- Protecting the existing ecosystems.

- Restricting the new development in the existing greener in risked areas. 
- Using the pavement material on roads or large parking spaces that increasing the surface reflectivity (sunrises) to cooling the air such as grass lanes or lightcolored materials.

- Providing a network of open spaces (green network), which is a habitat for many ecosystems and recreation for human.

- Providing a green infrastructure in urban areas include open spaces, gardens, plants, sidewalks, outdoors recreational facilities, green roofs, and green walls.

- Providing bluespace, including lakes, pools, ponds and canals in urban areas to decrease heat stress.

- Providing shading in public spaces to reduce also heat stress (for example, through the narrow streets or trees in streets).

- Increasing the ventilation through orientation and formulation of buildings and streets to limit access of solar energy.

\section{7-2-Adaptation Mechanisms in Urban Systems:}

Climate change is a major challenge for urban areas in all over the world's settlements. Its impacts on population are happening and will increase in the coming decades (coastal flooding and drought). Adaptive responses will determine the development level in the community (responses from developers, urban designers, politicians, and stakeholder). The strategic plans will determine our ability to adapt with challenges across a variety of scales, at least to lead to better results and to be less devastating and costly.

\section{7-3-Adaptation Via Urban and Regional Planning:}

Adaptation to climate change at any area (new and existing communities) requires well-design with landscape, which provides major chances to reduce GHGs, improves air quality and creates a space for recreation and ecosystems. So, adaptation is adding a value to quality of land use. Effective adaptation in the urban environment needs to be supported by a strong policy, a set of incentives to ensure real implementation, stakeholders participation, strategic environmental assessment (SEA), and other interventions.

Sustainable environment included green and blue spaces is useful for natural cooling, where water storage capacity and rainwater leaking, besides the visual benefits. Cities will face a cruel summer, which increased use of air conditioners. This is not only accelerated severe climate change impacts, but also have social implications as happen now in Egypt (shortage of energy). Urban and activities are emitting a big ratio of GHGs, which accelerated with high density. The flexible cities are facing the challenge, including extreme events, beaches erosion, coastal flooding and sea level rise, which return their conditions to be less vulnerable to climate change impacts. Among these adaptation options in urban areas are the following:

- Supporting vegetation system to reduce beach erosion by importing sand to protect the beaches or to decrease heating.

- Preventing new development in the high-risk areas.

- Enhancing methods of costal engineering to protect existed settlements.

- Retreat or shifting back away from inundation areas to save lives.

- Emergency plan for evacuation during catastrophic events.

The landuse flexibility in urban planning is required to adapt with extreme events. Green areas can be used in emergency times as shelters for harmed people. 
Complex environmental interactions require strict regulations, strong strategies and effective urban planning.

\section{7-4- Adaptation Via Making of Decisions and Plans in Urban Areas:}

Costs of adaptation should involve in costs of planning processes. Costs of anticipatory adaptation (adaptation before expected climatic impacts) are less than reactive adaptation (adaptation as a response to negative climatic phenomenon). So, adaptation should be associated early with cities plans. The scale of adaptation plans is varied from national planning to local planning. These plans should be as the following:

- Determining a precise strategic framework, visions and objectives, according to circumstances to every area.

- Developing spatial plans for risked areas from local authorities.

- Providing a national guidance or codes for urban planners. In addition to, reviewing these plans, and monitoring these plan process.

The integration between adaptation and development plans is a chance to grouping more participation from many stakeholder parts. Also, integration between adaptation with climate change and developmental plans is limiting the environmental issues and its future impacts on urban, socio-economic issues. The integrated institutional system is very important tool against climate change impacts, which able to monitor and model the risks to be involved in plans. The adaptation process includes the following:

- Identifying adaptation options.

- Reviewing to current policies for integration with the adaptation plans.

- Formulating the new policies and modifying the existing policies.

- The integration between adaptation programs and other urban programs.

- Establishing the institutional mechanisms to guide the adaptation process.

\section{7-5-Adaptation Via Infrastructure Planning and Architecture:}

The planned urban is using the permeable pavement (permeable asphalt for streets, paved sidewalks, greening of parking, green roofs, spaces landscape ...etc.). These methods are increasing the collected surface water, also decreasing heat island impacts in urban areas. The developed cities are trying to limit traditional pavements and rain water disposal systems. So, "going with nature" approach is more benefit than "controlling in nature" approach from many aspects (economic, social, and environmental).

\section{7-6-Adaptation with SLR Via Urban Policies and Strategies:}

Coastal systems are affected by natural changes and human practice that lead to corrosion or deposition. It was found from pervious indicators that coastline is so variable that approved by current evidences. So, it should be considered the uncertainty approach in the areas planning. Among the most important issues in coastal areas are the soil landing, erosion and unsustainable material exploitation, which need to establish controls in urban areas.

There are basic lines talking about mechanisms of planning to strengthen coastal community's capacity to cope with natural hazards, to adapt to impacts of climate change, and to maximize new opportunities resulting from changing climatic conditions. All of those refer to the right exploitation in light of the environmental assessment of projects, as well as the implementation of laws and regulations, also ensuring of the reality implementation of urban cities, whether on the local or regional 
level, with especial interesting for green and blue areas in open spaces and recreational activities.

So far, all adaptation methodologies are followed mechanisms of mitigation or adaptation policies with climate change risks induced SLR, or together, which have focused on use of market to make use of carbon more expensive, application of environmental standards, building codes and management needs for energy and water through design and clean use, in addition to proposing incentives and laws to improve land management, reducing intensity and direct to green areas inside and outside the building. Also, it should be included within program implications of disaster reduction with a series of decisions in case of floods and other events. There are many adaptation options such as urban density adaptation, land use change, institutional adaptation and sustainable development. Many of leading cities have started in the world to meet the need to adapt to impacts, which moved towards green cities.

Sea level rise is too serious issue facing coastal sectors future, where the threat with land loss, that depended on its importance or sensitivity ${ }^{3}$. There are many uncertainty approaches of adaptation to face it, such as anticipatory and reactive adaptation, which driven to many strategies, such as protection (a reactive strategy to protect people, property and infrastructure from sea level rise and is the first traditional response in many parts of the world for long-term planning in highly vulnerable locations through coastal engineering, such as seawalls, dunes, offshore breakwaters, gabions, cliff drains, boreholes), accommodation (an adaptive strategy that allows continued occupation of coastal areas while changes are made to urban and infrastructure by retrofitting a building or making it more resilient to sea level rise impacts) and retreat (an adaptive strategy to withdraw, relocate or abandon private or public assets at risk due to sea level rise by landuse planning, development controls, etc.).

Adaptation and mitigation to climate change induced SLR are a vital demand to vulnerable coasts to sustain their existence. It should be an integration between response strategies (protection, retreat, accommodation, and etc.), supporting them by merging with other programs, ICZM, adapting expulsion policies in low-lying risked areas, and etc.

These SLR strategies are directly aiming to access to shoreline, recreational activities, public facilities on the beaches, and educational activities (marine research). Also, they are increasing the visual values of indoor spaces, sedimentation in erode areas, and conservation on ecosystem.

\section{7-7- Integrating/Merging Adaptation with/in Disaster Risk Reduction:}

Climate change is one of recent risks. Climate change impacts can be very serious on properties and livelihoods. Storms, cyclones, coastal flooding, and diseases (from increased temperature) are causing of many dramatic disasters. But if we try to avoid the development in risked areas from the beginning, it can provide many benefits and reduce vulnerabilities. So, disaster risk reduction (DRR) approach is applied on risks of climate change impacts also, which should be managed carefully.

To make our communities more flexible is by appropriate approaches and standards to deal with disasters in urban areas, which are proceeded by precise framework to identify the used tools and resources. These tools include the following:

\footnotetext{
${ }^{3}$ IPCC, 2007.
} 
- Public awareness with extreme events (heat waves, floods and storms), also educating citizens to be prepared in emergency times.

- Searching for socio-economic abilities to increase the adaptive capacity.

- Early warning systems and emergency/evacuation plans.

- Providing financial aids for risked people, especially from low-income in risked areas.

- Appling risk assessment or SEA based on accurate data to any new and existed projects.

- Upgrading the existed infrastructure and facilities to be shelters for risked people in emergency times.

- Providing laws and codes to integrate with land use planning for adaptation.

- Strengthening the cooperation between governance parts and other private sectors to ensure the implementation of legal procedures (institutional adaptation).

\section{7-8-Density Adaptation Policy Via Different Approaches:}

The invitation to compact cities is an approach used before building the new communities to decrease transport networks, services concentration, mixed land uses and cultural diversity. Sometimes compact cities lead to high density, which can contribute to environmental and physical vulnerabilities (increase the risk intensity of climate change impacts because of GHGs emissions, degradation, pollution, over load on services). Regulations and appropriate approaches can make balance between urban systems to face climate change impacts. On other hand, some communities invite to low-density, as happened in developing parts (Africa, south Asia), which can be compacted as it is. So far, there is no clear vision about increased density approach in settlements, but it can work at developed countries. There is other trend towards the decentralization policy to spread or expand to suburbs (smart communities) during half of the nineteenth century.

\section{7-9-Sustainable Development and Practical planning as Adaptation Cores:}

The sustainable development is not only protecting the environment and creating chances, but also generating its own financial resources. The legislative framework and good urban planning are confirming sustainability approach. In Egypt, the development of the North Coast does not consider the sustainable development in its concept or management process, even projects that concern for environmental standards did not succeed in their design or construction via sustainable development plan. The changes in land use should be considered in risked areas to avoid percent from hazards. For instance, the developed cities in coastal zones try to turn lowlands to be agriculture lands, fishers farms and recreation areas. Also, they try to increase the vegetation size inside the urban districts.

\section{8- Adaptation Barriers:}

- Weakness of public understanding to risks of global climate change impacts (decreased awareness).

- Uncertainty about the impacts scope (decreased scientific research).

- Looking for others to take decisions.

- Focusing on anticipatory adaptation costs instead of future risk costs if did not adapt.

- The difficulty in obtaining of political leader's interest with adaptation.

- The difficulty in obtaining of stakeholders interest with adaptation.

- Difficult coordination between government departments.

- Inadequate resources. 


\section{9- Learned Lessons from International Experts in Adaptation with Climate Change:}

The international experiences are many, which put a number of decisions in urban planning, design and other fields ${ }^{4}$. What was revised from these experiences, found that Egyptian policies have a lot of lacking from many measures and policies to reach to safety line, especially at local level. Hence these impacts are still affecting on coastal areas that need to urgent adaptation. It is proved by the coming explained experiences.

In the United States, most cities seek to mitigation and adaptation with climate change impacts. Mitigation and adaptation options include innovative policies in land use planning, public transportation, forest conservation, greening roofs and planting, coastal protection by coastal management, modified urban codes and waste management. The government of the United Kingdom is sponsoring a wide range of national activities for planning and consulting in directing to specific policies that dealing with land use planning for climate change, which includes both mitigation and adaptation responses. At the regional level in the United Kingdom, there were many strategies that focus on climate change impact on coastal regions. Also, it works with Sustainability Assessment (SA). New Zealand is renewing its policies related to climate change, such as Resource Management Law, which governs planning, environmental assessment and energy use.

European countries are developing many policies on basis of urban scale (neighbourhood scale), such as strategic environmental assessment (SEA) in projects to be a zero carbon, renewable energy technologies, environmental performance of homes, upgrading urban areas, restoration, renewal urban and public participation in actions and emergency plans. The other options are evaporation (from cooling an array of green fairways, smaller open spaces, street trees, green roofs and blue spaces). These polices aim to sustainable communities with well design (indoors) and network of open spaces (outdoors) in the neighbourhood scale, which providing important opportunities for climate change adaptation.

In the region of Gulf countries, the adaptation has been reconsidered in context of integration with other policies, urban planning, design, and management process. Urban planning policies are aiming to landscape of open spaces, shading, moderate density, green cities, sand stabilization by vegetation, change in building codes to face increased heat or sea level rise, retreat the coastal settlements to safe areas, upgrading infrastructure, maintaining the space lands to be an emergency shelter (multi function of landuse) and buffer zones. Egyptian policies related to climate change are enacting programs of improving water quality, recycling industrial waste and sewage, constructing sea walls, rained agriculture on coastal areas to be self-sufficient of food and water, renewal energy, impact assessment of wastewater storage in northern lakes, public awareness about the lack of water, evaluating the social and economic impacts, building the research and institutional measures, developing the meteorological centres, integration between institutions and universities, and lastly developing a methodology to assess effects in scenarios.

\section{0- Conclusions:}

Global climate change is influencing negatively on communities, which decrease the life quality of human and ecosystems. For example, rising temperatures

\footnotetext{
${ }^{4}$ Metropolis International Institute, 2009.
} 
and humidity will decrease the thermal comfort, raise demand on air conditions, increase droughts, and increase the diseases. On other hand, climate change has a range of consequences on health, assets, economic activities and social systems, according to the settlement's vulnerability.

Global responses to global climate change are mitigation and adaptation, with helping from other programs such as sustainability and disaster programs. These responses have focused on environmental standards, building codes, management of energy and water via design and sustainable use, incentives, laws, land management, reducing density, and green areas. Also, these responses must be included within other programs (disaster reduction, sustainability).

Developed countries have adapted with climate change impacts, which moved towards greening and renewable energy inside and outside buildings. Adaptation faces some barriers such as poor understanding of effects, uncertainty, and difficulty of obtaining stakeholder or politicians on one decision table. The international experiences are many, which developed innovative policies and strategies. What was revised from Egyptian expert, it had been found that there is still a lot of lacking in many measures and policies to reach to safety line, especially at local level that still affected and need to urgent adaptation.

All of previous Adaptation mechanisms at urban areas (new and existing communities) reduce carbon emissions, improve air quality, decrease demand for energy, and create a space for recreation and wildlife, and other benefits. Adaptation to climate change impacts requires well-design (indoors) with landscape (outdoors), which a huge opportunity to raise the quality standards of life in our communities. So, adaptation is adding another value to quality of land use and other socio-economic indicators.

\section{REFERENCES:}

1. Abu-Zeid, M. and Abdel-Dayem, S. (1992), "Egypt Programmes and Policy Options for Facing the Low Nile Flows", Oxford.

2. Aerts, J. (2009, December Wednesday 2). Research Highlights. Retrieved June Saturday 22, 2013, from National Climate Research, Netherlands.

3. Allaby, Michael (2009), "Atmosphere, A Scientific History of Air, Weather, and Climate, Facts On File", Inc., Infobase Publishing, New York.

4. Assessment Report of the IPCC (2007), Cambridge University Press, Cambridge UK.

5. Barry, R. and Chorley R. (2003)," Atmosphere, Weather and Climate", Eighth Edition, Routledge , London.

6. Bigio, A.G. (2002), "Cities and Climate Change", A discussion paper for the World.

7. Bolin, Bert (2007), "A History of The Science And Politics Of Climate Change, The Role of the Intergovernmental Panel on Climate Change", Cambridge University Press, Cambridge, UK. 
8. Broadus, J., Milliman, J., Edwards, S., Aubrey, D. and Gable, F. (1989), "Rising sea level and damming of rivers possible effects in Egypt and Bangladesh In: Effect of changes of Stratospheric Ozone and Global Climate", ed. J. Titus, EPA.

9. Bruce, J., M. Egener and D. Noble (2005), "Municipal risk management for climate change. Presentation to the Climate Change Impacts and Adaptation National Conference", Montreal, Quebec, May 4-6, 2005.

10. C40 Cities. (2011, November 4), "Case Study - Climate Proof Adaptation Strategy 2010". Retrieved from C40 Cities - Climate Leadership Group: http://www.c40.org/case_studies/climate-proof-adaptation-strategy-2010

11. C40 Cities. (2012, April 27). "Case Studies - The NYC Green Infrastructure Plan". Retrieved from C40 Cities - Climate Leadership Group: http://www.c40.org/cities/newyork/case_studies

12. C40 Cities. (2012, June 4). "Case Study - Rotterdam Climate Initiative". Retrieved from C40 Cities - Climate Leadership Group: http://www.c40.org/case_studies/rotterdam-climate-initiative

13. Carter, TR., Parry, M.L., Harasawa, H., Nishioka, S. (1994), "IPCC technical guidelines for assessing climate change impacts and adaptation", WGII of IPCC. WMO/UNEP, Geneva.

14. Chambers, A. (2011), "Lessons to be learned from SE Asia floods", The Guardian.

15. Connell, R. (2005b), "Presentation to Workshop 1: Developing a climate adaptation strategy for the City of London", London. July 10, 2005.

16. World Bank (2007), "A Comparative Analysis", World Bank Policy Research Working Paper 4136, February.

17. Dasgupta, S., B. Laplante, S Murray, and D. Wheeler (2009), "Sea-Level Rise and Storm Surges".

18. Dasgupta, S., Laplante, B., Meisner, C., Wheeler, D., \& Yan, J. (2007), "The Impact of Sea Level Rise on Developing Countries: A Comparative Analysis. Washington", World Bank.

19. Davidson, F. (2011, November 14), "Bridging Borders - Integrated Strategic Planning for Cities and Regions", (F. Davidson, Performer) Housing \& Building National Research Center (HBRC), Giza, Cairo, Egypt.

20. Davidson, F. (2013, March 6), "Preparing for the strategic plan - A bridge to the future", (F. Davidson, Performer) Institute of Housing and Urban Development Studies (IHS), Rotterdam, South Holland, The Netherlands.

21. Delta coast, Journal of Coastal Research 11 (Journal of Coastal Research) 11, no. 821-833.

22. Development Report (2003), World Bank.

23. EEAA (1995, 1999), "Framework of National Action Plan for Dealing with Climate Change", U.S. 
24. El Raey M., Frihy, O.; Nasr S.M; Dewidar Kh (1998), "Vulnerability assessment of sea level rise over Port- Said Governorate ", Egypt. Environ. Monit. Assess 56: $113-128$

25. El Raey Mohamed; Dia El Quosy; Mahmoud El Shaer; Osama El Kholy and Ayat Soliman (1996)," Egypt: Inventory and Mitigation options and vulnerability and adaptation Assessment", Position paper; COP6, Berlin.

26. El Raey, M. (1997), "Vulnerability assessment of the coastal zone of the Nile delta of Egypt to the impacts of sea level rise", In: Ocean and Coastal Management 37: 2940 .

27. El Raey, M. (1997), "Vulnerability of the Nile Delta Coastal Zone of Egypt to the Impact of Sea-Level Rise".

28. El Raey, M. Y. Fouda and S. Nasr (1997), "GIS assessment of the vulnerability of Rosetta area", Egypt. In: Impacts of Sea Rise; Environ Monit. Assess 47: 59-77.

29. El Raey, M., Kh. Dewidar, and M. El Hattab (1999), "Adaptation to the impacts of sea level rise in Egypt".

30. El Raey, M., O. Frihy, S.M. Nasr, S. El-Kaffas, S. Ahmed, Y. Fouda, G.M. ElHattab, and G. Kh. Dewidar (Undated), "Vulnerability of the Coastal Zone of Egypt to Sea Level Rise". PDF file. U.S. Country Studies Program, Washington, DC.

31. El Raey, M., S. Nasr, O. Frithy, S. Desouki, and K. Dewidar, K. (1995), "Potential impacts of accelerated sea-level rise on Alexandria Governorate, Egypt", Journal of Coastal Research, Special Issue No. 14,

32. Hicks, R., (2005), "Senior Engineer, Regional Utility Planning, Policy and Planning".

33. Howell, D., (2006), "Air Quality and Climate Initiative", Department of Natural Resources and Parks, King County, Washington, Interviewed by authors, Seattle, Washington. April 26.

34. IPCC, (2007), "Contribution of Working Group I to the Fourth Assessment Report of the Intergovernmental Panel on Climate Change", edited by Solomon, S., D. Qin, M. Manning, Z. Chen, M. Marquis, K.B. Averyt, M. Tignor, and H.L. Miller, Cambridge University Press, Cambridge, UK and New York, NY.

35. Jobbins, Guy (2008), "Adaptation to the Impacts of Sea Level Rise in the Nile Delta Coastal Zone".

36. Leary, N., Adejuwon J., and Barros V. (2008), "Climate Change and Adaptation", London.

37. Leary, N., and Kulkarni J. (2007), "Climate Change Vulnerability and Adaptation in Developing Country Regions", Draft Final Report of the AIACC Project, Washington: The International START Secretariat.

38. McBean, G. and D. Henstra. (2003), "Climate Change, Natural Hazards and Cities", ICLR Research Paper Series - No. 31, Institute for Catastrophic Loss Reduction, Toronto. 
39. McGuire Elsner, J. Littell, and L Whitely Binder (eds). Center for Science in the Earth System, Joint Institute for the Study of the Atmosphere and Oceans, University of Washington, Seattle, WA.

40. McKinney, Vanessa (2007), "Sea Level Rise and the Future of the Netherlands, Inventory of Conflict and Environment", ICE Case Studies, 212. May.

41. Metropolis International Institute: Climate Change, Cities In Action, Imprimerie Expressart, Montreal (Quebec), Canada, 2009.

42. NEAA (2004), "Netherlands Environmental Assessment Agency: Dutch dikes, and risk hikes", A thematic policy evaluation of risks of flooding in the Netherlands, Extended summary, Bilthoven.

43. Roaf, S, Crichton D., and Nicol F. (2005), "Adapting Buildings and Cities for Climate Change".

44. Rosenzweig, C., W.D. Solecki, and R. Slosberg. (2006),"Mitigating New York City's Heat Island with Urban Forestry, Living Roofs, and Light Surfaces", A report to the New York State Energy Research and Development Authority.

45. Otto Simonett; UNEP/GRID-Arendal. (2006), "Nile Delta: Potential Impact of Sea Level Rise", Retrieved from GRID Arendal - A Centre Collaborating with UNEP:

46. Tabo and R.; Yanda, P. (2007), "Climate Change 2007: Impacts, Adaptation and Vulnerability", Cambridge University Press.

47. Thayer, J., Rider, M., \& Lerch, D. (2013), "Resilient against what?: How leading U.S. municipalities are understanding and acting on resilience", Santa Rosa, California: Post Carbon Institute.

48. World Health Organization, WHO/GWP Associated Programme On Flood Management: Urban Flood Risk Management, A Tool For Integrated Flood Management, 2008. 


\section{الملخص:}

إن خطر تغير المناخ هو أحد التهديدات البيئية على جودة حياة الإنسان والنظم البيئية. يعد ارتفاع درجات الحرارة والرطوبة من التأثثرات الخطيرة ، مما يقلل من الراحة الحرارية ، ويزبد الطلب على أجهزة مكيفات الهواء ، ويزيد من معدلات الجفاف ، ويزبد من نسب الأصابة بالأمراض. كما يؤثز ارتفاع مستوى سطح البحر والأحداث المناخية المتطرفة على المناطق الساحلية. بالإضافة إلى ذللك سيؤثز تغير المناخ بالسلب على الصحة العامة والأنشطة الاقتصادية والنظم الاجتماعية. ويتم الإستجابة لقضية تغير المناخ بآليات التخفيف أو التكيف ، أو كلاهما معا. ويتم العمل بسياسات التخفيف من خلال خلق معايير وتتريعات مناسبة والألتزام بقوانين البناء المحدة والطاقة المتجددة والإدارة الرشيدة لاستخدام المياه والمناطق الخضراء. وهناك العديد من خيارات التكيف في التخطيط الحضري مثل الكثافة الحضرية المثلى لحالة المنطقة ، والتغيير فى استخدام الأراضي ، والتغيير الهيكلى المؤسسي ، والتتمية المستدامة ، وتتسيق الفراغات العمرانية. وكما تعمل بعض الدول على تسريع عجلة التكيف داخل المدن. فى حين، يجب العمل على تطوير السياسات المصرية لتجنب المخاطر المستقبلية على المناطق العمرانية. ومن ثم ، فإن عملية التكيف للمجتمعات تعتبر هى أداه حيوية لتحسين جودة الهواء ، وخفض الطلب على الطاقة ، وخلق مساحة للترفيه والنظم البيئية ، وغيرها من الفوائد ، وهي أيضا فرصة كبيرة لرفع معايير الجودة داخل مجتمعاتتا. لذا ، فإن التكيف يضيف قيمة أخرى لجودة استخدام الأراضي وغيرها من العوامل الاجتماعية والإقتصادية الأخرى. 